\title{
In Vitro Enzymatic Determination of the Protein Nutritional Value and the Amount of Available Lysine in Extruded Cereal-based Products
}

\author{
Inger BJÖRCK, Teruyoshi MATOBA* and Baboo M. NAIR \\ Food Chemistry, Chemical Centre, University of Lund, Sweden \\ * Research Institute for Food Science, Kyoto University, \\ Uji, Kyoto 611, Japan \\ Received July 2, 1984
}

\begin{abstract}
An in vitro method, using proteolytic enzymes for protein hydrolysis, was used to evaluate the effect of extrusion cooking on protein quality. The products studied were protein-enriched biscuits processed in a twin-screw extruder under different conditions. In the product processed at low temperature $\left(170^{\circ} \mathrm{C}\right)$, the digestibility was comparable with that of the raw material. With increasing temperature $\left(170\right.$ to $\left.210^{\circ} \mathrm{C}\right)$, the in vitro availability of amino acids decreased. This decrease was most pronounced in the case of lysine, but the recovery of methionine, arginine, glycine, aspartic acid and aspargine was also affected. A loss of lysine, methionine and arginine could also be detected after acid hydrolysis. The total amount of lysine present in the raw material was not completely available, as judged from the in vitro assay as well as from balance experiments in rats. With increasing severity of heat treatment, the loss of biologically available lysine was more pronounced than the loss of total lysine. However, the loss of enzymatically available lysine was in good agreement with the results obtained in animal experiments. An increase in moisture content of the feed during processing, from 13 to $18 \%$, improved the availability of lysine in particular.
\end{abstract}

The biological value and amino acid content are important criteria of the nutritive quality of protein. Heat treatment of plant materials generally improves the digestibility of the protein, due to, e.q. the inactivation of protease inhibitors and other antiphysiological substances. With an increasing severity of heat treatment, the protein digestibility usually decreases. The biological availability of amino acids is affected by processing through different mechanisms. The sulphurcontaining amino acids are sensitive to oxidation. The availability of lysine in particular is affected by the Maillard reaction - a reaction between reducing sugars and free amino groups in the protein, causing a decrease in protein digestibility and in the availability of amino acids involved.

Extrusion cooking is a process that is being increasingly used in the food industry for precooking and forming mainly cereal-based products such as breakfast cereals, bread products and gruels. ${ }^{1)}$ The process conditions used during extrusion cooking - high temperature in combination with low water content-are known to favour the Maillard reaction. Some reports exist on the effect of extrusion cooking on the available lysine. ${ }^{2 \sim 4)}$ However, only few data have been reported of the effects on other essential amino acids. The effect of processing on protein quality has been studied using various in vivo and in vitro methods. ${ }^{5,6} \mathrm{~A}$ commonly used chemical method is based on amino acid analysis after acid hydrolysis. Acid hydrolysis as it is normally applied (in $6 \mathrm{~N} \mathrm{HCl}$ at $110^{\circ} \mathrm{C}$ for $20 \sim 24 \mathrm{hr}$ ) may present some problems such as the incomplete release of amino acids, e.g. valine and isoleucine, or the destruction of certain amino acids, e.g. methionine serine and threonine. Thus the amino acid composition of the acid hydrolysate may differ from that of the protein from which it is derived. Further, lysine bound to Maillard reaction products and peptides containing D- 
amino acids that are not available to physiological enzymes in the intestinal tract will also be hydrolyzed. To improve these shortcomings, several chemical methods that are more biologically relevant have been developed for the determination of certain "critical" amino acids such as lysine and methionine. The availability of lysine alone can be determined by the TNBS-method, ${ }^{7)}$ the FDNB-method, ${ }^{8)}$ of after guanidination. ${ }^{9)}$ However, in a previous study on extruded materials, the FDNB-method underestimated the loss of biologically available lysine at severe process conditions. ${ }^{4)}$

The enzymatic hydrolysis of food proteins, and subsequent analysis of the liberated amino acids, would provide a more biologically relevant in vitro method for evaluating the protein quality. Several enzyme systems have been suggested. ${ }^{10,11)}$ Recently, an in vitro method was published using only physiological proteases. ${ }^{12)}$ The purpose of the present investigation was to apply this method to study the effect of extrusion cooking on amino acid availability. The products studied were protein-enriched biscuits processed in a Creusot-Loire BC 45 twin screw extruder under different conditions. The content of amino acids determined after enzymatic hydrolysis was compared with that obtained after acid hydrolysis in raw and extruded materials. A comparison was also made with the content of biologically available lysine, determined through nitrogen balance experiments in rats.

\section{MATERIALS AND METHODS}

Materials. A mixture containing $42 \%$ wheat flour, $20 \%$ corn starch (Fleurine Corn Products, U.S.A.), 20\% finely ground sucrose, $11 \%$ soy protein isolate (Promine D, Central Soya), 6\% sodium caseinate (low viscosity, Francexpa, 75, Paris, France) and 1\% sodium chloride was thoroughly mixed (M 20\% Lödige Mixer, Paderborn, West Germany) before extrusion.

Extrusion procedure. The raw material was processed in a Creusot-Loire BC 45 twin screw extruder under four different conditions regarding moisture content of the feed and process temperature (see Table I). The mass temperature and pressure were measured in the compression chamber just before the die with a TPT 463 E Dynisco probe (Westwood, Mass., U.S.A.). Minimum residence time was determined by using erythrosin and was close to $42 \sim 44 \mathrm{sec}$. The screw diameter was $44.2 \mathrm{~mm}$ and the screws consisted of five segments (feed-CCCRC-die; $\mathrm{C}=$ compression, $\mathbf{R}=$ reverse flighted). The die was rectangular and had a height of $1.5 \mathrm{~mm}$, a width of $22.3 \mathrm{~mm}$ and a length of $47 \mathrm{~mm}$.

Sample preparation. All samples were packed in aluminium polyethylene bags under vacuum and stored at $-20^{\circ} \mathrm{C}$ until analysis. Before analysis, the samples were ground to pass through a $0.5 \mathrm{~mm}$ screen.

Chemical analysis. Nitrogen content was determined by the Kjeldahl method. Total amino acid content after acid hydrolysis $\left(6 \mathrm{~N} \mathrm{HCl}, 110^{\circ} \mathrm{C}, 24 \mathrm{hr}\right)$ was analysed by ionexchange chromatography on Durrum D 500 equipment. The sulphur-containing amino acids were determined after performic acid oxidation. Tryptophan was analysed spectrofluorometrically after incubation with papain in urea. ${ }^{13)}$ Enzymatically available amino acids were analyzed on a Hitachi 835 Amino Acid analyser. ${ }^{12)}$

Enzymatic hydrolysis. Pepsin-pancreatin digestion and amino-peptidase-prolidase hydrolysis were carried out as described earlier. ${ }^{12)}$ The samples were treated with pepsin in $0.1 \mathrm{~N} \mathrm{HCl}$ for $3 \mathrm{hr}$ at $37^{\circ} \mathrm{C}$. After neutralization, an incubation was performed with pancreatin for $20 \mathrm{hr}$ at $37^{\circ} \mathrm{C}$. The reaction was stopped by boiling for $5 \mathrm{~min}$. The pepsin-pancreatin digest was further treated with $\mathrm{CN} \mathrm{Br}$ Sepharose-bound aminopeptidase and prolidase for $24 \mathrm{hr}$

TABle I. Extrusion Conditions

Mass temperature and pressure measured just before the die.

\begin{tabular}{lcccccc}
\hline Product & $\begin{array}{c}\text { Moisture } \\
\text { content of } \\
\text { feed }(\%)\end{array}$ & $\begin{array}{c}\text { Feed rate } \\
(\mathrm{kg} \text { wet wt/hr) }\end{array}$ & $\begin{array}{c}\text { Screw speed } \\
(\mathrm{rpm})\end{array}$ & $\begin{array}{c}\text { Mass temp. } \\
\left({ }^{\circ} \mathrm{C}\right)\end{array}$ & $\begin{array}{c}\text { Pressure } \\
\text { (bars) }\end{array}$ & $\begin{array}{c}\text { Minimum } \\
\text { residence } \\
\text { time }(\mathrm{s})\end{array}$ \\
\hline I & 13 & 40 & 80 & 170 & $195 \sim 200$ & 42 \\
II & 13 & 40 & 80 & 193 & $150 \sim 160$ & 42 \\
III & 13 & 40 & 80 & 210 & $95 \sim 105$ & 44 \\
IV & 18 & 40 & 80 & 210 & $75 \sim 85$ & 44 \\
\hline
\end{tabular}


at $37^{\circ} \mathrm{C}$. After filtration, the hydrolysate was used for the amino acid determination.

Biological assay of available lysine. Biologically available lysine was determined through nitrogen balance experiments in rats. ${ }^{4)}$ Based on the amino acid requirement of the growing rat given by NAS/NRC ${ }^{14)}$ lysine was made limiting in the test diets by mixing the sample under investigation with wheat gluten and certain free amino acids. In order to get a quantitative measure of the available lysine, nitrogen balance experiments were also performed on standard diets, containing known amounts of lysine at limiting levels. The complete composition of the test and standard diets was as previously described. ${ }^{4)}$

\section{RESULTS}

Amino acid analysis following acid hydrolysis

The amino acid composition of the samples determined after acid hydrolysis and their recovery relative to the content in the raw material is shown in Table II. The recovery of some of the essential amino acids was lower in the processed samples, particularly in those which were processed at higher temperatures. There was about a $13 \%$ loss of total lysine in the sample extruded at $170^{\circ} \mathrm{C}$ (product I) and $37 \%$ in the sample extruded at $210^{\circ} \mathrm{C}$ (product III). Other amino acids which show some decrease in recovery $(>10 \%)$ were methionine, arginine, cystine and tryptophan. Under the most severe conditions of extrusion $\left(210^{\circ} \mathrm{C}\right.$ and $13 \%$ moisture, product III), the loss of these amino acids was $29,21,14$ and $12 \%$ respectively.

In the raw material as well as in products I, II and IV, the sulphur-containing amino acids were limiting. However, the lysine loss in product III became so severe that lysine formed the limiting amino acid. An increase in moisture content of the feed during extrusion from 13 to $18 \%$ (product IV) improved the

Table II. Amino Acid Composition (mg/g protein) of the Raw Material and Extruded Samples (Determined after ACId Hydrolysis)

\begin{tabular}{|c|c|c|c|c|c|c|c|c|}
\hline \multirow{2}{*}{$\begin{array}{l}\text { Amino acid } \\
\text { Isoleucine }\end{array}$} & \multirow{2}{*}{$\begin{array}{c}\begin{array}{c}\text { FAO/WHO } \\
1973^{15}\end{array} \\
40\end{array}$} & \multicolumn{2}{|l|}{ Raw } & I & II & III & \multicolumn{2}{|c|}{ IV } \\
\hline & & \multicolumn{2}{|l|}{47} & $46 \quad(98)$ & $47(100)$ & $45 \quad(96)$ & 45 & (96) \\
\hline Leucine & 70 & \multicolumn{2}{|l|}{84} & $81 \quad(96)$ & $82 \quad(98)$ & $82 \quad(98)$ & 82 & (98) \\
\hline Lysine & 55 & \multicolumn{2}{|l|}{63} & $54 \quad(87)$ & $49 \quad(77)$ & $39 \quad(63)$ & 45 & (72) \\
\hline \multirow[t]{2}{*}{ Methionine $^{a}$} & & \multicolumn{2}{|l|}{$21]$} & $18\}(86)$ & $16)(76)$ & 15 (71) & \multicolumn{2}{|c|}{15 (71) } \\
\hline & 35 & & \multirow[t]{2}{*}{35} & 31 & 28 & 27 & & 27 \\
\hline Cystine $^{a}$ & & \multirow{2}{*}{\multicolumn{2}{|c|}{$\begin{array}{l}14 \\
52\end{array}$}} & $13^{J}(93)$ & $12^{J}(86)$ & $12{ }^{J}(86)$ & \multicolumn{2}{|c|}{$12 \int_{(86)}$} \\
\hline \multirow[t]{2}{*}{ Phenylalanine } & & & & 47 (90) & 46 (88) & 50 (96) & \multicolumn{2}{|c|}{49 ] (94) } \\
\hline & 60 & & \multirow{2}{*}{93} & 84 & 82 & 88 & & 86 \\
\hline Tyrosine & & $41^{J}$ & & 37 J $(90)$ & $36^{\mathrm{J}}(88)$ & 38 (93) & 37 & (90) \\
\hline Threonine & 40 & \multicolumn{2}{|l|}{41} & $38 \quad(93)$ & $39 \quad(95)$ & $39 \quad(95)$ & 40 & (98) \\
\hline Tryptophan $^{b}$ & 10 & \multicolumn{2}{|l|}{17} & $17(100)$ & 16 (94) & $15 \quad(88)$ & 15 & (88) \\
\hline Valine & 50 & \multicolumn{2}{|l|}{53} & $50 \quad(94)$ & $51 \quad(96)$ & $51 \quad(96)$ & 50 & (94) \\
\hline Aspartic acid & & \multicolumn{2}{|l|}{93} & $91 \quad(98)$ & 92 (99) & $89 \quad(96)$ & 90 & (97) \\
\hline Serine & & \multicolumn{2}{|l|}{63} & $57 \quad(90)$ & $57 \quad(90)$ & $60 \quad(95)$ & 60 & (95) \\
\hline Glutamic acid & & 240 & & $240(100)$ & $240(100)$ & $231 \quad(96)$ & 234 & (98) \\
\hline Proline & & 84 & & $81 \quad(96)$ & $81 \quad(96)$ & 87 (100) & 84 & (100) \\
\hline Glycine & & 37 & & $35 \quad(95)$ & $33 \quad(89)$ & $36 \quad(97)$ & 35 & (95) \\
\hline Alanine & & 39 & & $36 \quad(92)$ & $37 \quad(95)$ & $39(100)$ & 38 & (97) \\
\hline Histidine & & 27 & & $26 \quad(96)$ & 25 (93) & $25 \quad(93)$ & 25 & (93) \\
\hline Arginine & & 61 & & $61(100)$ & $50 \quad(82)$ & $48 \quad(79)$ & 51 & (84) \\
\hline Limiting amin & acid & $\mathrm{Met}+\mathrm{Cy}$ & & Met + Cys & Met + Cys & Lys & Met - & + Cys \\
\hline Chemic & 1 score & 100 & & 89 & 80 & 71 & & 77. \\
\hline
\end{tabular}

( ): Recovery of amino acids ( $\%$ of raw material).

a Performic acid oxidation.

$b$ Spectrofluorometrical assay. 
Table III. Amino Acid Composition (mg/g protein) of the Raw Material and Extruded Samples (Determined after EnZymatic Hydrolysis)

\begin{tabular}{|c|c|c|c|c|c|c|c|c|}
\hline \multirow{2}{*}{$\frac{\text { Amino acid }}{\text { Isoleucine }}$} & \multirow{2}{*}{$\frac{\text { Raw }}{47}$} & I & \multicolumn{2}{|c|}{ II } & \multicolumn{2}{|c|}{ III } & \multicolumn{2}{|c|}{ IV } \\
\hline & & $45 \quad(96)$ & 42 & (89) & 40 & $(85)$ & 41 & (87) \\
\hline Leucine & 80 & $78 \quad(98)$ & 74 & (93) & 71 & (89) & 71 & (89) \\
\hline Lysine & 57 & $54 \quad(95)$ & 39 & (68) & 31 & (54) & 37 & (65) \\
\hline Methionine & 17 & $16 \quad(94)$ & 15 & (88) & 13 & (76) & 13 & (76) \\
\hline Cystine & Traces & Traces & \multicolumn{2}{|c|}{ Traces } & \multicolumn{2}{|c|}{ Traces } & \multicolumn{2}{|c|}{ Traces } \\
\hline Phenylalanine & 49 & $49(100)$ & 45 & $(92)$ & 44 & (90) & 44 & $(90)$ \\
\hline Tyrosine & 40 & $40(100)$ & 37 & (93) & 36 & (90) & 37 & (93) \\
\hline Threonine & 31 & $30 \quad(97)$ & 28 & (90) & 26 & (84) & 28 & (90) \\
\hline Tryptophan & 12 & $12(100)$ & 11 & (92) & 10 & (83) & 9 & (75) \\
\hline Valine & 51 & $50 \quad(98)$ & 47 & (92) & 45 & (88) & 46 & (90) \\
\hline Aspartic acid + asparagine & 48 & $40 \quad(83)$ & 37 & (77) & 33 & (69) & 37 & (77) \\
\hline Serine & 40 & $38 \quad(95)$ & 35 & $(88)$ & 33 & (83) & 36 & $(90)$ \\
\hline Glutamic acid + glutamine & 157 & $151 \quad(96)$ & 137 & (87) & 130 & (83) & 137 & (87) \\
\hline Proline & 76 & $72 \quad(95)$ & 67 & $(88)$ & 63 & (83) & 65 & (86) \\
\hline Glycine & 26 & $25 \quad(96)$ & 22 & $(85)$ & 20 & (77) & 21 & $(81)$ \\
\hline Alanine & 33 & $32 \quad(97)$ & 30 & (91) & 28 & (85) & 29 & $(88)$ \\
\hline Histidine & 17 & $19(100)$ & 15 & (88) & 14 & $(82)$ & 15 & $(88)$ \\
\hline Arginine & 52 & $54(100)$ & 43 & (83) & 39 & (75) & 42 & (81) \\
\hline
\end{tabular}

( ): Recovery of amino acids ( $\%$ of raw material).

retention of lysine in particular.

\section{Amino acid analysis following enzymatic hydrolysis}

In Table III the amino acid composition after enzymatic hydrolysis is presented. The amount of cysteine was so low that it was difficult to quantify from the chromatograms. The content of certain amino acids in the raw material was lower than the corresponding values obtained after acid hydrolysis. The recovery of aspartic acid + asparagine was about $50 \%$, and that of glutamic acid + glutamine, tryptophan, serine, glycine and histidine ranged from $60 \sim 70 \%$. The content of other amino acids in the raw material was comparable to that obtained after acid hydrolysis.

In the product processed at low temperature (product I), the in vitro digestibility appears to be comparable with that of the raw material. However, with increasing process temperature, the in vitro availability of amino acids decreased. Lysine was the most seriously affected, but at severe conditions there was a general decline in the availability of all the amino acids. The decrease in methionine, ar- ginine, glycine and aspartic acid + asparagine was most pronounced, $23 \sim 31 \%$. An increase in moisture content during processing from $13 \%$ (product III) to $18 \%$ (product IV) improved the enzymatic availability of lysine in particular.

\section{Determination of lysine content by various methods}

In Table IV, the recovery of lysine determined with different methods can be compared: total lysine after acid hydrolysis, biologically available lysine and enzymatically available lysine. Biologically available lysine has been calculated both from the biological value (BV) as well as from the net protein utilization (NPU), also taking into account the effects on protein digestibility. The lysine content in the raw material, determined biologically and by the enzymatic method, was lower than that obtained after acid hydrolysis. In the product processed under mild conditions, the loss in total lysine was very similar to the loss of biologically available lysine, about $13 \%$. However, the loss of lysine determined after enzymatic hydrolysis was less pronounced, 
Table IV. Lysine Content in Raw and Extruded Products

\begin{tabular}{|c|c|c|c|c|}
\hline \multirow{3}{*}{ Sample } & \multicolumn{4}{|c|}{ Lysine $\mathrm{mg} / \mathrm{g}$ protein } \\
\hline & \multirow{2}{*}{$\begin{array}{c}\text { Total } \\
\text { Acid hydrolysis } \\
(\%)\end{array}$} & \multicolumn{2}{|c|}{ Available } & \multirow{2}{*}{$\begin{array}{c}\text { Enzymatic } \\
\text { hydrolysis } \\
(\%)\end{array}$} \\
\hline & & $\begin{array}{l}\text { BV } \\
(\%)\end{array}$ & $\begin{array}{l}\text { NPU } \\
(\%)\end{array}$ & \\
\hline Raw material & $63(100)$ & $55(100)$ & $51(100)$ & $57(100)$ \\
\hline \multicolumn{5}{|l|}{ Extruded: } \\
\hline $\begin{array}{l}\mathrm{I}\left(170^{\circ} \mathrm{C}, 13 \%\right. \\
\left.\mathrm{H}_{2} \mathrm{O}, 80 \mathrm{rpm}\right)\end{array}$ & $54 \quad(87)$ & $48 \quad(88)$ & $45 \quad(87)$ & $54 \quad(95)$ \\
\hline $\begin{array}{r}\text { II }\left(193^{\circ} \mathrm{C}, 13^{\circ} \%\right. \\
\left.\mathrm{H}_{2} \mathrm{O}, 80 \mathrm{rpm}\right)\end{array}$ & $49 \quad(77)$ & $40 \quad(73)$ & $36 \quad(70)$ & $39 \quad(68)$ \\
\hline $\begin{array}{c}\text { III }\left(210^{\circ} \mathrm{C}, 13 \%\right. \\
\left.\quad \mathrm{H}_{2} \mathrm{O}, 80 \mathrm{rpm}\right)\end{array}$ & $39 \quad(63)$ & $31 \quad(56)$ & $26 \quad(50)$ & $31 \quad(54)$ \\
\hline $\begin{array}{c}\text { IV }\left(210^{\circ} \mathrm{C}, 18 \%\right. \\
\left.\mathrm{H}_{2} \mathrm{O}, 80 \mathrm{rpm}\right)\end{array}$ & $45 \quad(72)$ & $38 \quad(70)$ & $34 \quad(65)$ & $37 \quad(65)$ \\
\hline
\end{tabular}

( ): Relative value.

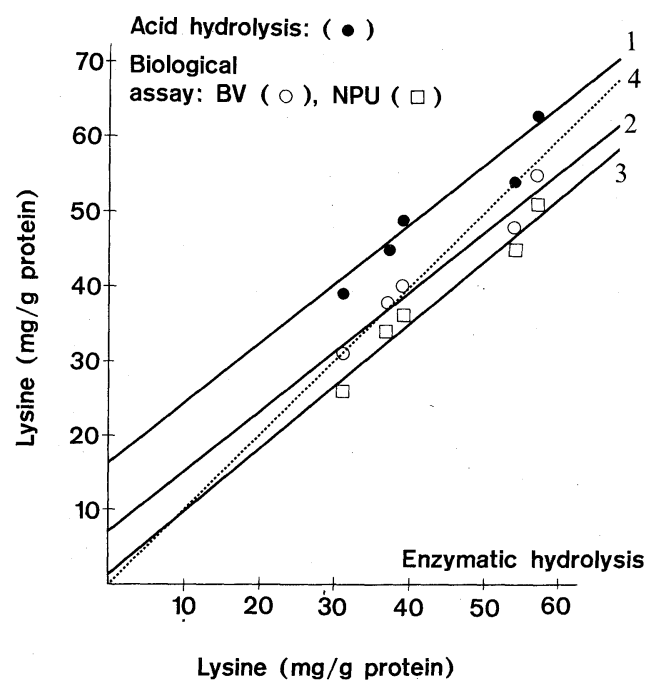

FIG. 1. Total - and Biologically Available-Lysine as a Function of Enzymatically Available in Raw and Extruded Samples.

(1) Total lysine:,$y=0.767 X+16.567(r=0.95)$. Biologically available lysine: (2) (BV) $\bigcirc, y=0.803 X+7.363(r=$ $0.98)$; (3) (NPU) $\square, y=0.849 X+1.401$ ( $r=0.98)$; (4) ------, $y=X$.

about $5 \%$. With an increasing severity of heat treatment, the biological assay shows a more pronounced loss than total lysine. In contrast, the loss in enzymatically available lysine was in good agreement with the results obtained in vivo.
In Fig. 1, the total and biologically available lysine, calculated from the BV and the NPU values, has been plotted versus the enzymatically available lysine. There is a good correlation between the biological (BV, NPU) and the enzymatic methods, whereas the values obtained after acid hydrolysis deviate, particularly at low lysine levels.

\section{DISCUSSION}

The protein sources used in the present study were wheat flour, soy isolate and caseinate. The average recovery of enzymatically released amino acids from this raw ingredient mixture was about $80 \%$, indicating that the amino acids were not completely available. When using the same in vitro method on pure proteins (glutelin, glutenin, caseine, albumin), the recovery ranged from $80^{\circ} \sim 100 \%{ }^{\circ}{ }^{12}$ )

The loss of certain amino acids-lysine, methionine, tryptophan and arginine - during extrusion could be detected after both acid and enzymatic hydrolysis. No reducing sugars were added to the raw material, which only contained minute amounts of reducing sugars originally present in the ingredient mixture. However, during extrusion cooking, hydrolysis of sucrose ${ }^{3)}$ or $\operatorname{starch}^{16)}$ may occur, thus providing reactive carbohydrates that can 
participate in the Maillard reaction.

In a similar study, ${ }^{17)}$ Köhler followed the changes in amino acid composition during extrusion cooking of maize grits with varying moisture content. Lysine was the most seriously affected by a decrease in moisture content of the feed. In addition to a loss in enzymatic availability, the total lysine content determined after acid hydrolysis also decreased. In contrast, the availability of aspartic acid, tyrosine and arginine was reduced, while the total content of these amino acids remained unaffected even at low moisture contents. The addition of $1 \%$ glucose during extrusion caused losses in the content of lysine $(45 \%)$, methionine $(22 \%)$ and cysteine $(19 \%)$ that could be detected after acid hydrolysis. Thus, although lysine is most prone to deterioration during extrusion cooking, depending on the process conditions and recipe, other amino acids may also suffer losses.

It has been suggested that the energy input to the extruder (mechanical, thermal) has an impact on amino acid retention. ${ }^{17)}$ At a low energy input during the extrusion of maize grits, there was an increase in the availability of most amino acids. This general increase in the enzymatic availability in vitro under mild process conditions may conceal losses in the availability of individual amino acids due to, for example, the Maillard reaction. This could explain the results obtained with product $I$ in our study, where the loss in enzymatically available lysine was less pronounced then that detected after acid hydrolysis.

The beneficial effect of an increased moisture content of the feed on lysine retention in this study is in agreement with other reports. ${ }^{3,17,18)}$ An increase in moisture content from 13 to $18 \%$ at $210^{\circ} \mathrm{C}$ was about as effective in reducing lysine damage as a reduction in process temperature by $17^{\circ} \mathrm{C}$ at $13 \%$ moisture.

Our results suggest that under mild process conditions during extrusion cooking of a protein-enriched biscuit, the main mechanism of lysine damage is destruction. At more severe conditions there is also a loss in enzymatic availability, which is not revealed by chemical methods.

In a previous study on the same products, the FNDB method (1-fluoro 2,4-dinitro benzene) was used for the determination of available lysine. ${ }^{4)}$ In the product processed under the most severe conditions (product III), the FDNB method indicated a more moderate loss of lysine $(37 \%)$ than the nitrogen balance experiment, possibly due to the decreased protein digestibility. In contrast, in this study the loss of available lysine determined with the enzymatic method $(54 \%)$ agreed very well with that indicated from the NPU value $(50 \%)$ in this product.

By definition, the BV does not take into account the effects on protein digestibility. However, undigestible peptides, formed due to the Maillard reaction, may be absorbed intact by the rat and excreted in the urine. ${ }^{19,20)}$ Thus, the true digestibility (TD) may underestimate the actual decrease in availability to proteolytic enzymes after processing.

We conclude that the enzymatic method used in this study provides a useful tool for the determination of amino acid availability in processed foods.

Acknowledgments. The authors wish to thank Professor Jean-Claude Cheftel, Laboratoire de Biochimie et Technologie Alimentaires, Université des Sciences et Techniques du Languedoc, Montpellier, France and Professor Nils-Georg Asp, Dept. of Food Chemistry, University of Lund, Sweden for valuable advice and discussions.

\section{REFERENCES}

1) P. Linko, P. Colonna and C. Mercier, "Advances in Cereal Science and Technology," Vol. IV, ed. by Y. Pomeranz, American Association of Cereal Chemists Inc., St. Paul, 1981, pp. 145 235.

2) M. J. Beaufrand, J. F. de la Guérivière, C. Monnier and B. Poullain. Ann. Nutr. Aliment., 32, 353 (1978).

3) A. Noguchi, K. Mosso, C. Aymard, J. Jeunink and J. C. Cheftel, Lebensm. Wiss. Technol., 15, 105 (1982).

4) I. Björck, A. Noguchi, N-G. Asp, J. C. Cheftel and A. Dahlqvist, J. Agric. Food Chem., 31, 488 (1983).

5) C. Den Hartog and D. Pol, "Protein and Amino Acid Functions," ed. by E. J. Bigwood, Pergamon Press, New York, 1972, pp. $347 \sim 353$.

6) P. R. Payne, "Protein and Amino Acid Functions," ed. by E. J. Bigwood, Pergamon Press, New York, 
1972, pp. $381 \sim 388$.

7) M. L. Kakade and I. E. Liener, Anal. Biochem., 27, 273 (1969).

8) V. H. Booth, J. Sci. Food Agric., 22, 658 (1971).

9) J. A. Maga, J. Food Sci., 46, 132 (1981).

10) R. L. Hill and W. R. Schmidt, J. Biol. Chem., 237, 389 (1962).

11) B. M. Nair, R. Öste, N-G. Asp and A. Dahlqvist, $J$. Agric. Food Chem., 24, 386 (1976).

12) T. Matoba, E. Doi, D. Yonezava, R. Öste and B. M. Nair, Agric. Biol. Chem., 46, 465 (1982).

13) R. Öste, B. M. Nair and A. Dahlqvist, J. Agric. Food Chem., 24, 1141 (1976).

14) NAS/NRC "Nutrient Requirement of Laboratory Animals," Washington, DC, 1972, No. 10.

15) FAO/WHO, W.H.O. Tech. Rep. Ser., No. 522
(1973).

16) J. Owusu-Ansah, F. R. van de Voort and D. W. Stanley, Cereal Chem., 60, 319 (1983).

17) F. Köhler, Veränderung der ernährungsphysiologischen und physikalischen Eigenschaften von Getreidemahlerzeugnissen durch Extrusion unter besonderer Berücksichtigung proteinangereichter Produkte. Dissertation, Institut für LebensmittelTechnologie, Berlin, 1981.

18) T. F. Tsao, Available Lysine Retention during Extrusion Processing, Dissertation, Colorado State University, 1976.

19) J. Valle-Riestra and R. H. Barnes, J. Nutr., 100, 873 (1970).

20) A. Pronzuk, D. Pawlowska and J. Bartnik, Nutr. Met., 15, 171 (1973). 